\title{
A FINANCIAL PERFORMANCE COMPARISON OF CZECH CREDIT UNIONS AND EUROPEAN COOPERATIVE BANKS
}

\author{
Matěj Kuc, Petr Teplý*
}

\begin{abstract}
This paper empirically assesses the financial performance of Czech credit unions in relation to other European cooperative banks in terms of their profitability and stability. We created a unique dataset of 283 cooperative banks from 15 European countries in the period 2006-2013. Using the system GMM and alternative panel data methods, we reveal worse performance of Czech credit unions in terms of both profitability and stability compared to their European peers. We also argue that big credit unions in the Czech Republic have assumed a non-sustainable business model depending on excessive risk taking while enjoying implicit subsidy via deposit insurance. In conclusion, we argue that under recent capital management policies, big Czech credit unions will likely face serious financial problems in coming years.
\end{abstract}

Keywords: credit union, cooperative banking, moral hazard, system GMM, Z-Score JEL Classification: C23, G21, L25

\section{Introduction}

Credit unions in the Czech Republic were traditional financial institutions that made financial services accessible to the general population before the Second World War. They were subsequently abolished by the political regime of that time and were no longer relevant to the mainstream development in Western Europe. Czech credit unions founded after the fall of communism suffered from a poor legislative framework that did not reflect trends and developments in cooperative banking of the second half of the $20^{\text {th }}$ century. Their boom turned into a severe crisis of the sector in 1999. Czech credit unions regained lost customer confidence after a few years of stagnation but some of the leading credit unions have got into problems again recently, and their licenses have been revoked.

The aim of this paper is to compare the financial performance of Czech credit unions with cooperative banks in other European countries. We analyse the differences in profitability and risk between Czech and European financial cooperatives. We will focus specifically on two groups of indicators: (i) profitability indicators encompassing Return on Average Assets (ROAA), Return on Average Equity (ROAE), Net Interest Margin (NIM) and

* Matěj Kuc, Charles University in Prague, Institute of Economic Studies, Czech Republic (matejkuc@seznam.cz);

Petr Teplý, Faculty of Finance and Accounting, University of Economics, Czech Republic, (petr.teply@vse.cz).

Financial support from GAČR (Project No. 16-21506S), GAUK (Projects No. 105815

and No. 488317) and VŠE (Project No. VŠE IP100040) is gratefully acknowledged. 
(ii) a stability indicator (Z-Score). Empirical analysis will be carried out using the dynamic panel data method (system GMM) where applicable. Alternative panel data methods will serve as supplementary techniques.

The structure of the paper is as follows. Section 2 presents a literature review covering the financial performance of cooperative banks with a primary focus on Europe. In Section 3 we describe the selection process for variables and describe the data sample. Section 4 explains our methodological approach (system GMM and alternative panel data methods). In Section 5, we test two hypotheses concerning the low profitability and the high risk level of Czech credit unions. This section also summarises key results and findings of this paper. Finally, Section 6 concludes the work and states the final remarks.

\section{Literature Review}

Based on a literature review of relevant works, we have identified a lack of empirical studies assessing the financial performance of credit unions in the new EU member states. There are two main reasons to which we can attribute this gap: insufficient data availability and a smaller relative share of the cooperative banking business in these countries. Since we are not able to find a common point, we split this literature review into two separate streams: the first one describes the general condition of the Czech credit union sector; the second one is focused on the performance drivers of cooperative banks' profitability and stability in Europe.

The first group includes the works by IMF (2012), MFČR (2014) and Tomšík (2015) and deals with a structural difference between Czech credit unions and cooperative banks elsewhere in Europe. The three mentioned analyses show that Czech credit cooperatives behave like small and risky commercial banks by denying baseline cooperative principles. However, these studies are lacking any econometrical analysis of these conclusions. Although some of the most striking problems in the legislative framework that led to the credit union sector crisis in 1999, such as a lack of proper supervision or a limitation of scope of business, have been resolved by new regulation, some issues still remain. Dvorák (2004) showed the high dependency of Czech credit unions on interest rate-sensitive deposits - credit unions needed to attract members' deposits on savings products bearing significantly higher interest rates than commercial banks. Full deposit insurance of deposits and common Deposit Insurance Funds with less risky commercial banks further promoted the moral hazard of depositors who did not have to distinguish the riskiness of individual deposit-taking institutions. As IMF (2012) and Tomšík (2015) pointed out, the trend of high interest rates on deposits was still present in the Czech credit union sector.

Ayadi et al. (2010) highlight that there is no single universal model of cooperative banking in Europe. However, there are basic principles shared by cooperative banking models across Europe. Interestingly, Czech credit unions do not follow some of these principles. An example is that Czech credit unions do not follow the "one member one vote" principle as members are allowed to buy additional membership shares and consequently have higher voting power at general meetings. Members of Czech credit unions also do not seem to share common bonds as is typical for cooperatives according to 
the World Council of Credit Unions (WOCCU, 2011). Despite their small size, Czech credit unions typically offer the whole range of products having branches all around the country - from this point of view, we cannot discern the market focus of individual institutions. By not sharing some of the cooperative best practices advised by the WOCCU, Czech credit unions are not members of this organisation. Matejašák and Teplý (2013) criticised new regulation in connection with low capital levels and possible problems of larger Czech credit unions associated with required capital increases. The problem of low equity levels is further intensified by a strategy of low prices for membership shares in order to attract new clients more easily. Low membership claims may harm the cooperative spirit of institutions as members are not motivated to follow the performance of the credit union, which once again denies a basic cooperative principle. Moreover, a significant concentration of ownership rights is suspect because additional membership shares formed more than $85 \%$ of total equity from membership shares in every Czech credit union in 2013.

The second body of literature focuses on the performance drivers of cooperative banks' profitability and stability in Europe. The papers in our review cover time periods from 1979 to 2009. Data samples were created solely by banks from Western Europe. Iannotta et al. (2006) showed that bigger cooperative banks and banks with a higher share of loans in their total assets are more profitable. Banks with more diversified income sources yield higher profits according to Goddard et al. (2010). The effect of the capitalto-asset ratio on profitability is ambiguous - Goddard et al. (2004) and Iannotta et al. (2006) found a positive correlation, whereas Goddard et al. (2010) a negative one and Beckmann (2007) found no statistically significant dependence. The effect of liquidity is insignificant according to Iannotta et al. (2006). Goddard et al. (2004) found a negative effect of the cost-to-income ratio on profitability. Market concentration has either no (Beckmann, 2007) or a negative effect (Goddard et al., 2010) and GDP growth seems to support banks' profitability (Iannotta et al., 2006; Beckmann, 2007). A low interest rate environment affects profitability negatively (Beckmann, 2007).

The studies interested in the risk factors of cooperative banks used distinct measures as proxies for banking stability such as the Z-Score, a ratio of non-performing loans or capital ratios. The effects of most of the variables on the stability of cooperative banks differ from paper to paper. Consensus has been reached on the negative effect of the bank's growth rate (Beck et al., 2009; Köhler, 2012) and of the cost-to-income ratio on the bank's stability (Hesse and Čihák, 2006; Beck et al., 2009; Ayadi et al., 2010). Liquidity (Iannotta et al., 2006; and Köhler, 2012) and GDP growth (Iannotta et al., 2006; Hesse and Čihák, 2006; Köhler, 2012) seem to have no effect on bank soundness. This is probably also the case for market concentration (Hesse and Čihák, 2006; Ayadi et al., 2010; Köhler, 2012), the capital-to-assets ratio (Iannotta et al., 2006), the loans-to-deposits ratio (Köhler, 2012) and inflation (Hesse and Čihák, 2006). A positive or no effect on stability has been found for the share of loans in total assets (Iannotta et al., 2006; Hesse and Čihák, 2007; Köhler, 2012) and also for income diversity (Hesse and Čihák, 2007; Beck et al., 2009; Köhler, 2012). The effect of size on stability has been found to be positive (Beck et al., 2009), statistically insignificant (Iannotta et al., 2006; Köhler, 2012) as well as negative (Hesse and Čihák, 2007; Ayadi et al. 2010). 


\section{Data Analysis}

The following section consists of two parts. First, we explain the variable selection process and then we describe the dataset used.

\subsection{Variable selection}

The selection of variables is based upon the empirical papers mentioned in the literature review section. Our goal is twofold: we want to assess profitability and stability. We will use three common measures as dependent variables that capture banking profitability:

Return on Average Assets: $R O A A_{i, t}=\frac{N E T I N C O M E_{i, t}}{\frac{A s_{i, t}+A s_{i, t-1}}{2}}$

Return on Average Equity: ROAE $E_{i, t}=\frac{N E T I N C O M E_{i, t}}{\frac{E q_{i, t}+E q_{i, t-1}}{2}}$

Net Interest Margin: NIM ${ }_{i, t}=\frac{\text { NET INTEREST INCOME }}{\frac{E A R_{-} A A s_{i, t}+E A R_{-} A s_{i, t-1}}{2}}$

The risk (or stability) of a bank is measured by the Z-Score. The Z-Score is a popular measure of banks' soundness. It is a quantity of standard deviations of net income that a company has to lose, under the assumption of normal distribution of income, so that all of its capital is depleted. We can alternatively imagine the Z-Score as a distance to the upper bound of insolvency. The higher the Z-Score, the lower the probability of going insolvent. We will use the time-varying Z-Score approach of Hesse and Čihák (2007):

$$
\operatorname{ZSCORE}_{i, t}=\frac{\operatorname{ROAA}_{i, t}+C A R_{i, t}}{\sigma(R O A A)_{i}}
$$

Where $C A R_{i, t}$ is the capital-to-assets ratio and $\sigma(R O A A) i$ is the standard deviation of ROAA for the bank $i$ over the whole sample period, as in our case 2006-2013. For further discussion about the usage of the Z-Score, we refer to Lepetit and Strobel (2013). A summary of the preselected list of explanatory variables is provided in Table 1. Because of our focus on Czech credit unions, we denote all the relevant banking figures in the Czech currency (CZK). 
Table 1 | List of Independent Variables

\begin{tabular}{|c|c|c|}
\hline Variable name & Description & Source \\
\hline In_As & logarithm of assets & \multirow{8}{*}{$\begin{array}{l}\text { authors based on BankScope } \\
\text { and annual reports }\end{array}$} \\
\hline$g r \_A s$ & annual growth rate of assets & \\
\hline$C A R$ & capital-to-assets ratio & \\
\hline Liquidity & liquid assets-to-total assets ratio & \\
\hline LtD & loans-to-deposits ratio & \\
\hline Loans Ratio & loans-to-assets ratio & \\
\hline Cost Income & cost-to-income ratio & \\
\hline Fee Ratio & net fee income-to-total income ratio & \\
\hline $\mathrm{HHI}$ & Herfindahl-Hirschman index & European Central Bank \\
\hline GDP & annual growth rate of real GDP & \multirow{4}{*}{ Eurostat } \\
\hline Unemployment & annual unemployment rate & \\
\hline Inflation & annual inflation rate & \\
\hline Interest Rate & $\begin{array}{l}\text { long-term interest rate } \\
\text { (gov. bond yield with } 10 \mathrm{Y} \text { maturity) }\end{array}$ & \\
\hline$C Z$ & dummy for Czech credit unions & authors \\
\hline
\end{tabular}

Source: Authors

\subsection{Data description}

We used the BankScope database as a data source for European cooperative banks and we enriched the dataset by using Czech credit unions' data retrieved from their annual reports to compensate for the lack of data on Czech credit unions in international databases. To deal with the double-counting issue, we used, similarly to Hesse and Čihák (2007), consolidated bank statements only in case no unconsolidated statements were available for the given institution. We used a dataset for 2006-2013 because of data availability. We included only cooperative banks which were active (had financial statements uploaded) for all the time periods in order to have a balanced dataset. Since a disproportionately large share of cooperative banks in the sample were from Germany and Italy, we randomly deleted some of them to receive more representative quantities for individual countries. Altogether, our data sample includes data from 15 European countries and consists of 283 cooperative banks. The data sample contains a full set of the $11 \mathrm{Czech}$ credit unions that were in operation for the whole period. 
Table 2 | Banks in Data Sample by Country

\begin{tabular}{|l|c|c|}
\hline Country & Count & Share \\
\hline Austria & 17 & $6.0 \%$ \\
\hline Belgium & 1 & $0.4 \%$ \\
\hline Bulgaria & 1 & $0.4 \%$ \\
\hline Cyprus & 1 & $0.4 \%$ \\
\hline Czech Republic & 11 & $3.9 \%$ \\
\hline Germany & 139 & $49.1 \%$ \\
\hline Denmark & 2 & $0.7 \%$ \\
\hline Spain & 12 & $4.2 \%$ \\
\hline
\end{tabular}

\begin{tabular}{|l|c|c|}
\hline Country & Count & Share \\
\hline Finland & 1 & $0.4 \%$ \\
\hline France & 7 & $2.5 \%$ \\
\hline Greece & 1 & $0.4 \%$ \\
\hline Croatia & 1 & $0.4 \%$ \\
\hline Italy & 87 & $30.7 \%$ \\
\hline Malta & 1 & $0.4 \%$ \\
\hline Slovenia & 1 & $0.4 \%$ \\
\hline SUM & $\mathbf{2 8 3}$ & $\mathbf{1 0 0} \%$ \\
\hline
\end{tabular}

Source: Authors

Let us take a look at the medians of the performance measures with the Czech credit unions separated from the rest of the sample. We see similar profitability of Czech and other European banking cooperatives in terms of ROAA (see Appendix Table A.3), but $\mathrm{Czech}$ credit unions reached significantly lower levels of ROAE. The difference in these two profitability measures can be explained by high capital-to-assets ratios of Czech credit cooperatives that reflect the higher risk of their business because their capital adequacy ratios are relatively small. CNB (2014) reported a 14.3\% capital adequacy of the Czech credit union sector as of the end of 2013, while other European cooperatives in our sample had capital adequacy 2 percentage points higher. This implies that assets with higher risk weights are present in portfolios of Czech credit unions (for further details, see Matejašák and Teplý, 2013).

Even though the median NIM of the Czech credit unions is only slightly higher compared to the rest of our sample, Figure 1 reveals a positive relationship between asset size and NIM of Czech credit cooperatives, hinting that especially bigger Czech credit unions may be conducting unnecessarily risky business. Both high need for capital and high NIM may be implied by the fact that credit unions under Czech law are not allowed to grant mortgage loans and therefore, they must focus on riskier activities such as consumer lending or real estate investment loans.

Strikingly different is the development of the Z-Score for both groups (see Figure 2). Whereas the median Z-Score of Czech credit unions decreased considerably in time, the median of other European cooperative banks increased and proved the strong resiliency of cooperative banking schemes in a time of crisis which was discussed by Ayadi et al. (2010) or by Liikanen et al. (2012). 
Figure 1 | Dependency of NIM on Asset Size of Czech Credit Unions (2013)

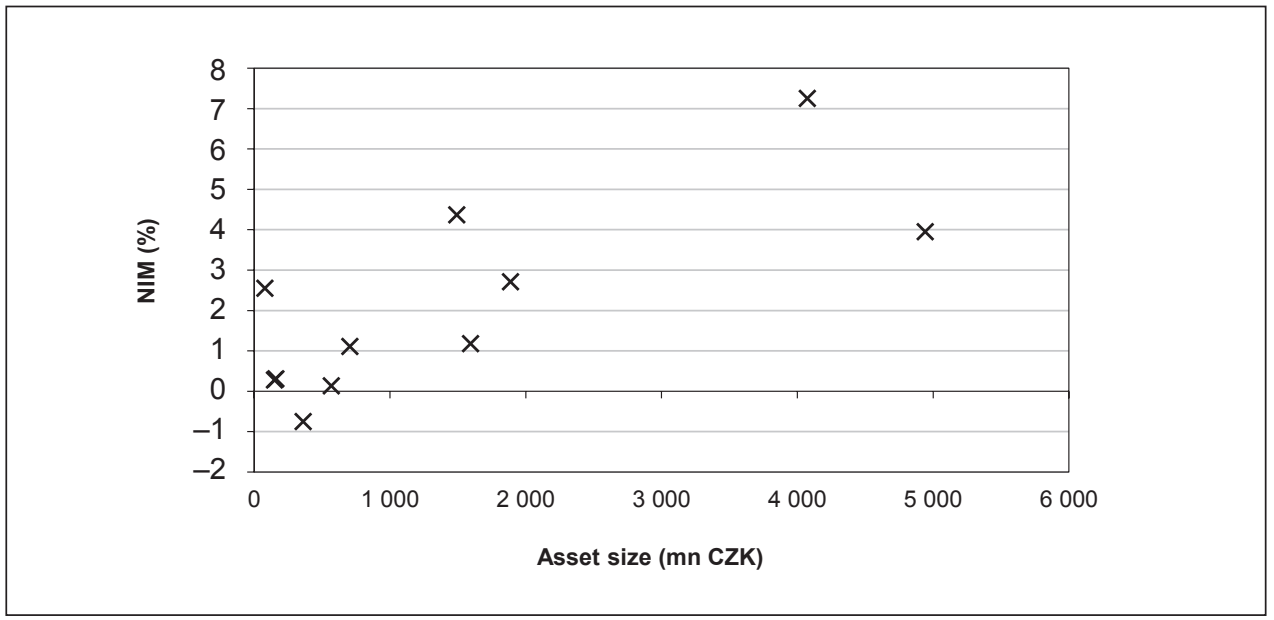

Note: crosses represent individual credit unions.

Source: Authors, based on BankScope and annual report data

Figure 2 | Medians of Z-Score of Czech Credit Unions (CZ) and EU Credit Unions (EU) in 2006-2013

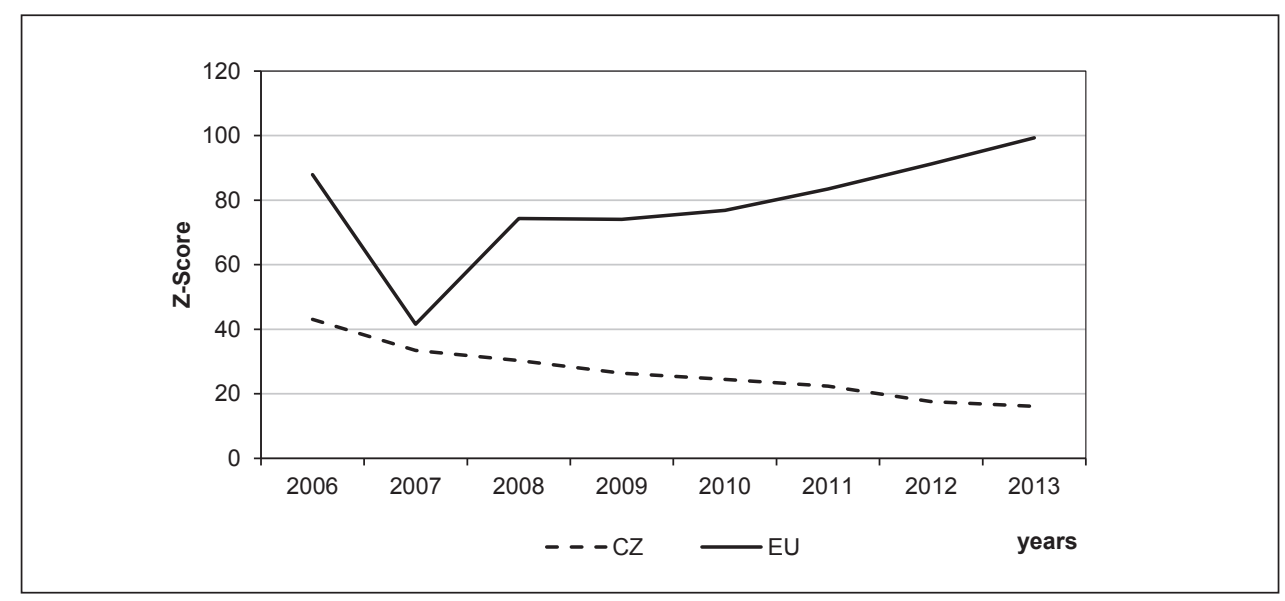

Source: Authors, based on BankScope and annual report data

Moreover, the evolution of Z-Scores of individual Czech credit unions based on their asset size reveals an interesting pattern (see Appendix A.1): a decreasing Z-Score with increasing institution size is easily recognizable for Czech credit unions. In other words, Czech credit unions grew bigger in time but their Z-Scores decreased. We can see no such pattern in the case of other European cooperative banks (Appendix A.2). An explanation for why mainly big Czech credit unions are vulnerable according to the Z-Score measure 
is quite straightforward. We have already shown that Czech credit unions need a high share of capital for their business models based on risky assets. Moreover, Czech credit unions are rather young institutions that grow much faster on average than their European peers (see Appendix A.3). Credit unions can raise capital either through membership shares or through retained earnings. Retained earnings form only a negligible share of Czech credit unions' equity - in 2013 it was only $3.6 \%$ of the equity of the whole sector and therefore, the majority of the equity comes from membership shares. Nevertheless, Czech credit unions charge only minimal amounts for the membership shares in order to attract new members and therefore, they are not able to raise enough equity for their growing business through methods other than selling additional membership shares to existing members (MFČR, 2014). These facts help to explain why the Czech National Bank has revoked, in the last couple of years, the licenses of only those credit unions that had expanded aggressively and belonged among the largest institutions of the Czech credit union sector.

Table A.3 in the Appendix provides descriptive statistics of all the variables used. We observe that Czech credit unions are generally smaller than European cooperative banks. We already mentioned above that Czech credit unions grow faster and have substantially higher capital-to-assets ratios. Czech credit unions tend to have similar ratios of loans to assets but they have lower ratios of loans to deposits. European cooperative banks tend to be more effective on average in terms of their cost-to-income ratios and they have a higher share of their income resulting from fees.

\section{Methodology}

Shehzad et al. (2009) found significant persistence in banks' profitability. Similar results were described by Goddard et al. (2004) or Athanasoglou et al. (2008). Delis and Kouretas (2011) and Köhler (2012) found persistence in banking risk measures and therefore suggested using dynamic panel models. Delis and Kouretas (2011) argued that the risk is persistent due to intertemporal risk smoothing, regulation, and the relationship with risky customers. Because of this evidence of persistence, we will use a dynamic panel data model, which we prefer over simple panel data methods for it can deal with so-called dynamic panel data bias. The system GMM can deal with endogeneity and leads to robust estimates when dealing with persistent variables. This method is becoming increasingly popular in empirical studies researching into banking profitability or stability (see, e.g., García-Herrero et al., 2009; Liu et al., 2013). Dynamic panel data models are characterised by including a lagged dependent variable $\left(y_{i, t-1}\right)$ among independent variables:

$$
\begin{gathered}
y_{i, t}=\alpha y_{i, t-1}+x_{i, t}^{\prime} \beta+\varepsilon_{i, t}, i=1, \ldots, N ; t=1, \ldots, T \\
\varepsilon_{i, t}=\mu_{i}+v_{i, t} \\
E\left[\mu_{i}\right]=E\left[v_{i, t}\right]=E\left[\mu_{i} v_{i, t}\right]=0
\end{gathered}
$$

where $x_{i, t}^{\prime}$ is a vector of independent variables, $i=1, \ldots, N$ is the individual's index and $t=1, \ldots, T$ stands for time. The error term $\varepsilon_{i, t}$ is composed of two terms: $\mu_{i}$ is the fixed effect and $v_{i, t}$ is the idiosyncratic shock. The OLS estimator is inconsistent in this case 
because a lagged dependent variable is correlated with the fixed error term (dynamic panel data bias). Nickell (1981) shows that the problem with fixed effects cannot be solved by using a group transformation. Bond (2002) suggests using both OLS and a group estimator as a robustness check for the GMM since both methods are likely to be biased in opposite directions.

There are two popular approaches to dealing with the above-mentioned endogeneity problem without the need for further correction. The first one is the difference general method of moments (difference GMM). The difference GMM uses first-differencing to get rid of fixed effects and, therefore, the problem with dynamic panel data bias (Arellano and Bond, 1991). The drawback of the difference GMM method is that it does not allow for time-invariant variables and hence we cannot use dummy variables to distinguish among different institutional types of banks. The second method is called the system GMM. It uses the additional assumption that the first differences of instrument variables are not correlated with the fixed effect term and it allows using time-invariant variables. The system GMM method was popularised by works of Arellano and Bover (1995) and Blundell and Bond (1998).

We use Windmeijer (2005) for the correction for standard errors because Arellano and Bond (1991) warn that the inclusion of too many instruments may create a downward bias of standard errors during two-step estimation and the method by Windmeijer (2005) corrects it. Our estimated model takes the following form:

$$
Y_{i, s, t}=\alpha+\beta Y_{i, s, t-1}+\gamma B_{i, s, t}+\delta C_{s, t}+\epsilon D_{s}+\vartheta T_{t}+\varepsilon_{i, s, t}
$$

where

$Y_{i, s, t} \quad$ is a bank performance measure for the bank $i$ in the country $s$ at the time $t$,

$Y_{i, s, t-1}$ is the first lag of the bank performance measure,

$B_{i, s, t}$ is a vector of bank-specific variables,

$C_{s, t} \quad$ is a vector of country-specific variables,

$D_{s} \quad$ is a dummy for Czech credit unions,

$T_{t} \quad$ is a vector of time dummies (years),

$\varepsilon_{i, s, t} \quad$ stands for a disturbance term, which is made up of two components: $\mu_{i, s}$ is the fixed effects term and $v_{i, s, t}$ stands for the idiosyncratic shock.

\section{Results and Findings}

In order to use the system GMM method correctly, we need to test the persistence of dependent variables to ensure the appropriateness of the dynamic panel data estimation method. We ran an Arellano-Bond test for autocorrelation for all four financial performance measures and we rejected the null hypothesis of no first order autocorrelation in the case of ROAA, ROAE and NIM. We found no autocorrelation of the Z-Score and we therefore used methods other than the system GMM for stability regressions.

Our primary interest is the effect of Czech credit union dummy variables and we therefore leave aside variables that are highly correlated with it because of the specific 
nature of Czech credit unions to avoid multi-collinearity problems (see correlation matrix in Appendix A.4). This holds true for bank size since Czech credit unions are generally smaller than European cooperative banks and due to specific Czech legislation, Czech credit unions have much more capital relative to assets (see Appendix A.3).

We decided to estimate models with the following bank-specific independent variables: growth of assets, liquid asset ratio, loans-to-deposits ratio and loans-to-assets ratio. The Herfindahl-Hirschman index, GDP growth rate, unemployment and inflation represent country-specific variables and, moreover, Czech credit unions and year dummies are included. Variance inflation factor (VIF) analysis finds no severe multi-collinearity among the variables used in the model as all the predictor variables have VIF smaller than 10.

\subsection{Profitability regression results}

We estimate a two-step system GMM model with robust standard errors. The lagged dependent variable is positive in all three cases and it is not significant only in the ROAA regression. Such an outcome is assumed because of persistence of banking profitability measures. The regression results show that profitability of Czech credit unions is smaller in terms of ROAA at the 1\% significance level and in terms of ROAE at the 5\% significance level. The model was indecisive in the case of the NIM. The coefficients were significant not only statistically but also economically.

The sign of the other explanatory variables was more or less expected: liquidity decreases profitability just as unemployment does. A higher loans-to-deposits ratio increases profitability but a higher share of loans in total assets decreases it. This shows that non-traditional banking activities may be more profitable than loan granting. The NIM is higher in an environment of higher inflation. An outcome that we did not expect is that the GDP growth rate has a negative effect on ROAA; nevertheless, its effect is insignificant in the other two profitability regressions.

All the F-tests strongly reject that variables are jointly insignificant. Arellano-Bond $\mathrm{AR}(1)$ and $\mathrm{AR}(2)$ tests for the first and second-order autocorrelation have a null hypothesis of no autocorrelation. We reject the null hypothesis for AR(1) in all the cases, which was expected because the first-order autocorrelation is assumed by the system GMM model with one lag. We cannot reject the hypothesis of no second-order autocorrelation and that is why no second lag is included in the model. The validity of the instruments is tested using a Hansen test. This test uses the null hypothesis that all instruments are valid. The null hypothesis of exogenous instruments was not rejected at the $5 \%$ level in all three regressions. Standard errors are presented in the brackets of Table 3.

Moreover, we perform a robustness check described by Bond (2002). We run OLS and fixed effects (FE) models and check whether the GMM estimate of a lagged dependent variable is above the FE estimate and below the OLS estimate. Both OLS and FE should suffer from dynamic panel data bias, which increases the estimate of the OLS and decreases the one of the FE. This test proved the validity of our GMM estimates (see Appendix A.5). 
Table 3 | Profitability Regression Results

\begin{tabular}{|c|c|c|c|}
\hline Dependent variable & ROAA & ROAE & NIM \\
\hline Lagged dependent variable & $\begin{array}{r}0.101 \\
(0.068)\end{array}$ & $\begin{array}{l}0.326^{* * *} \\
(0.070)\end{array}$ & $\begin{array}{c}0.310^{* *} \\
(0.144)\end{array}$ \\
\hline Constant & $\begin{array}{r}0.096 \\
(0.070)\end{array}$ & $\begin{array}{l}1.794^{* * *} \\
(0.610)\end{array}$ & $\begin{array}{l}0.080^{* * * *} \\
(0.024)\end{array}$ \\
\hline$g r_{-} A s$ & $\begin{array}{l}-0.017 \\
(0.018)\end{array}$ & $\begin{array}{l}-0.134 \\
(0.091)\end{array}$ & $\begin{array}{l}-0.004 \\
(0.005)\end{array}$ \\
\hline Liquidity & $\begin{array}{l}-0.076 \\
(0.069)\end{array}$ & $\begin{array}{l}-1.672^{* * *} \\
(0.612)\end{array}$ & $\begin{array}{l}-0.084^{* * *} \\
(0.024)\end{array}$ \\
\hline LtD & $\begin{array}{c}0.056^{*} \\
(0.034)\end{array}$ & $\begin{array}{l}0.268^{* * *} \\
(0.102)\end{array}$ & $\begin{array}{c}0.215^{* *} \\
(0.010)\end{array}$ \\
\hline LoansRatio & $\begin{array}{l}-0.085 \\
(0.070)\end{array}$ & $\begin{array}{l}-1.820^{* * *} \\
(0.624)\end{array}$ & $\begin{array}{l}0.069^{* * *} \\
(0.026)\end{array}$ \\
\hline HHI & $\begin{array}{r}1.433 \\
(1.017)\end{array}$ & $\begin{array}{c}38.59 * \\
(21.67)\end{array}$ & $\begin{array}{l}-7.906^{* * *} \\
(2.439)\end{array}$ \\
\hline GDP & $\begin{array}{l}-0.061^{* * *} \\
(0.012)\end{array}$ & $\begin{array}{r}0.390 \\
(0.387)\end{array}$ & $\begin{array}{l}-0.040 \\
(0.055)\end{array}$ \\
\hline Unemployment & $\begin{array}{l}-0.156^{* * *} \\
(0.045)\end{array}$ & $\begin{array}{l}-1.135^{* * *} \\
(0.226)\end{array}$ & $\begin{array}{r}0.001 \\
(0.021)\end{array}$ \\
\hline Inflation & $\begin{array}{l}-0.000 \\
(0.087)\end{array}$ & $\begin{array}{r}0.242 \\
(0.823)\end{array}$ & $\begin{array}{c}0.152^{* * *} \\
(0.040)\end{array}$ \\
\hline$C Z$ & $\begin{array}{l}-0.435^{* *} \\
(0.190)\end{array}$ & $\begin{array}{l}-7.511^{* * *} \\
(2.258)\end{array}$ & $\begin{array}{l}-1.423^{*} \\
(0.856)\end{array}$ \\
\hline \multicolumn{4}{|l|}{ Diagnostics } \\
\hline Number of observations & 1,981 & 1,981 & 1,981 \\
\hline Number of instruments & 38 & 38 & 32 \\
\hline Wald-test & $310^{* * *}$ & $358^{* * *}$ & $312^{* * *}$ \\
\hline Arellano-Bond AR(1) test & $-2.18^{* *}$ & $-3.80^{* * *}$ & $-2.46^{* *}$ \\
\hline Arellano-Bond AR(2) test & -1.61 & -1.26 & -1.12 \\
\hline Hansen test & $30.3^{*}$ & 19.1 & $23.6^{*}$ \\
\hline Year dummies & Yes & Yes & Yes \\
\hline
\end{tabular}

Note: Significance codes: ${ }^{* *}=0.01,{ }^{* *}=0.05,{ }^{*}=0.1$

Source: Authors, based on BankScope and annual report data 


\subsection{Stability regression results}

The Arellano-Bond AR(1) test found no serial correlation in the residuals. Moreover, the system GMM model with the Z-Score as a dependent variable performed generally poorly. We suspect no endogeneity if we exclude lag of the dependent variable from our model and we are therefore going to use a simpler panel data method. We follow the methodology of Beck et al. (2009), who use random effects to estimate bank risk expressed as the Z-Score. We prefer the random effects method over fixed effects since it allows us to include a time invariant dummy in the regression equation, which is crucial for our research.

Table 4 | Stability Regression Results

\begin{tabular}{|c|c|c|c|}
\hline Dependent variable & \multicolumn{3}{|c|}{ Z-Score } \\
\hline Method & RE & FE & pooled OLS \\
\hline Constant & $\begin{array}{c}96.67^{* *} \\
(38.11)\end{array}$ & $\begin{array}{l}102.0^{* * * *} \\
(22.54)\end{array}$ & $\begin{array}{l}-89.01 * \\
(46.47)\end{array}$ \\
\hline$g r \_A s$ & $\begin{array}{c}-0.305^{*} \\
(0.017)\end{array}$ & $\begin{array}{l}-0.028 \\
(0.017)\end{array}$ & $\begin{array}{r}-0.049 \\
(0.031)\end{array}$ \\
\hline Liquidity & $\begin{array}{l}-0.121 \\
(0.257)\end{array}$ & $\begin{array}{l}-0.230 \\
(0.301)\end{array}$ & $\begin{array}{l}1.769^{* *} \\
(0.606)\end{array}$ \\
\hline$L t D$ & $\begin{array}{c}0.601^{* * *} \\
(0.201)\end{array}$ & $\begin{array}{l}0.609^{* * *} \\
(0.192)\end{array}$ & $\begin{array}{l}-1.694 \\
(1.194)\end{array}$ \\
\hline LoansRatio & $\begin{array}{r}0.044 \\
(0.212)\end{array}$ & $\begin{array}{l}-0.049 \\
(0.232)\end{array}$ & $\begin{array}{l}1.814^{* * * *} \\
(0.480)\end{array}$ \\
\hline HнI & $\begin{array}{r}66.56 \\
(65.69)\end{array}$ & $\begin{array}{r}112.1 \\
(80.37)\end{array}$ & $\begin{array}{l}-169.1 \\
(102.5)\end{array}$ \\
\hline GDPgr & $\begin{array}{r}0.013 \\
(0.872)\end{array}$ & $\begin{array}{l}0.004 \\
(0.80)\end{array}$ & $\begin{array}{r}9.423 \\
(6.937)\end{array}$ \\
\hline Unemployment & $\begin{array}{l}-2.648^{* * *} \\
(0.445)\end{array}$ & $\begin{array}{l}-2.586^{* * *} \\
(0.447)\end{array}$ & $\begin{array}{l}-1.710 \\
(2.641)\end{array}$ \\
\hline Inflation & $\begin{array}{l}-1.873^{* *} \\
(0.974)\end{array}$ & $\begin{array}{l}-1.785^{*} \\
(0.956)\end{array}$ & $\begin{array}{l}-10.74^{*} \\
(5.616)\end{array}$ \\
\hline$C Z$ & $\begin{array}{l}-40.66^{* *} \\
(23.95)\end{array}$ & $\begin{array}{c}\text { omitted } \\
-\end{array}$ & $\begin{array}{l}-28.48^{* *} \\
(13.14)\end{array}$ \\
\hline \multicolumn{4}{|l|}{ Diagnostics } \\
\hline Number of observations & 2,264 & 2,264 & 2,264 \\
\hline F-test & - & $14.1^{* * *}$ & $17.0^{* * *}$ \\
\hline Wald test & $261^{* * *}$ & - & - \\
\hline R-sq. & 0.21 & 0.22 & 0.10 \\
\hline Year dummies & Yes & Yes & Yes \\
\hline
\end{tabular}

Note: Significance codes: ${ }^{* *}=0.01,{ }^{* *}=0.05,{ }^{*}=0.1$

Source: Authors, based on BankScope and annual report data 
We use the Hausman test to justify the usage of random effects. We cannot reject the null hypothesis of the Hausman test at the 5\% significance level, which means that both fixed effects and random effects are consistent but the random effects method is asymptotically more efficient. We also performed a Breusch-Pagan Lagrange multiplier test and we rejected the null hypothesis. It means that the OLS estimate is less efficient than random effects and that we should use the latter method.

Nevertheless, we still ran regressions using the fixed effects and the pooled OLS for comparison. As our data are grouped into clusters (countries), we suspect that standard errors may overstate the estimator precision, as was shown by Moulton (1986). Therefore, we use cluster-robust standard errors clustered at the country level as advised by Cameron and Miller (2015). As expected, we find considerably higher standard errors for cluster-robust errors compared to the non-clustered model. Therefore, we stick with the cluster-robust estimation.

We estimated the models with year dummies, just as in the profitability regressions. The results of the random and fixed effects regressions are very similar, which points to the robustness of our estimates (see Table 4). The results of the OLS regression differ for some variables but not for the variable of our interest - the dummy for Czech credit unions. The regression results showed that the $\mathrm{Z}$-Score of $\mathrm{Czech}$ credit unions is considerably lower than that of other European cooperative banks in our sample and, hence, Czech credit unions are much riskier.

\subsection{Summary of results}

Broadly speaking, the outcomes of our models showed poor performance of Czech credit unions in terms of both profitability and stability measures. We found that Czech cooperatives are less profitable than other European cooperative banks in terms of ROAA and ROAE. The difference in the NIM was statistically insignificant, which is surprising, especially given the criticism of high delinquency and the riskiness of credit unions' loan portfolios (Matejašák and Teplý, 2013; ČNB, 2014). Nevertheless, Figure 1 shows that the NIM of big Czech credit unions is higher than average and their business model can be considered more risky. Another problem is the very low stability of Czech credit unions compared to European ones. Moreover, Figure A.1 in the Appendix depicts the decreasing trend of Z-Scores for Czech credit unions, which is striking, especially for bigger institutions. Another important fact is that Czech credit unions are relatively small in size and their capital stock in absolute value is, together with their risky asset portfolio, a highly risky combination and it may be one of the reasons why larger Czech credit unions are currently under such pressure.

Table 5 shows that our results are often in line with other studies focused on the stability of cooperative banks, especially with Hesse and Čihák (2007) and Köhler (2012). We find only partial consensus with other surveyed studies. A variable which shows a different sign in our model than in other studies is GDP growth in profitability regressions - we estimated no statistically significant effect but the results of others (Iannotta et al., 2006; 
Beckmann, 2007) were positive. This may be caused by different time periods included in the dataset (this study's dataset is affected by the current economic crisis whereas the surveyed works are from pre-crisis times of moderate GDP growth). Otherwise, we see no clear contradiction to surveyed studies.

Table 5 | Comparison of Results with Existing Literature

\begin{tabular}{|c|c|c|c|c|c|c|}
\hline \multirow{2}{*}{$\begin{array}{l}\text { Dependent } \\
\text { variable }\end{array}$} & \multicolumn{3}{|c|}{ Profitability } & \multicolumn{3}{|c|}{ Stability } \\
\hline & Sign & In line & Against & Sign & In line & Against \\
\hline Growth of Assets & 0 & & & $-/ 0$ & $\begin{array}{l}\text { - Beck et al. (2009) } \\
\text { - Köhler (2012) }\end{array}$ & \\
\hline Liquidity & - & & $\begin{array}{l}0 \text { lannotta } \\
\text { et al. (2006) }\end{array}$ & 0 & $\begin{array}{l}\text { lannotta et al. } \\
(2006) \\
\text { 0/+ Köhler (2012) }\end{array}$ & \\
\hline $\begin{array}{l}\text { Loans to dep. } \\
\text { ratio }\end{array}$ & + & & & + & & 0 Köhler (2012) \\
\hline Share of Loans & - & & & 0 & $\begin{array}{l}\text { Hesse and Čihák } \\
\text { (2007) } \\
\text { Köhler (2012) }\end{array}$ & $\begin{array}{l}+ \text { lannotta et al. } \\
\text { (2006) }\end{array}$ \\
\hline $\begin{array}{l}\text { Market } \\
\text { concentration }\end{array}$ & 0 & $\begin{array}{l}\text { Beckmann } \\
(2007)\end{array}$ & $\begin{array}{l}\text { - Goddard } \\
\text { et al. (2010) }\end{array}$ & 0 & & $\begin{array}{c}+ \text { Beck et al. } \\
\text { (2009) }\end{array}$ \\
\hline GDP growth & 0 & & $\begin{array}{l}\text { + lannotta } \\
\text { et al. (2006) } \\
+ \text { Beckmann } \\
(2007)\end{array}$ & 0 & $\begin{array}{l}\text { lannotta et al. } \\
(2006) \\
\text { Hesse and Čihák } \\
\text { (2007) } \\
\text { Köhler (2012) }\end{array}$ & \\
\hline Unemployment & - & & & - & & \\
\hline Inflation & 0 & & & - & $\begin{array}{l}-10 \text { Hesse and } \\
\text { Čihák (2007) }\end{array}$ & $\begin{array}{l}+ \text { Beck et al. } \\
\text { (2009) }\end{array}$ \\
\hline
\end{tabular}

Source: Authors, based on cited papers

\subsection{Further research opportunities}

There are several ways to improve our research results, though they are robust. Firstly, a comparative analysis of performance of Czech credit unions with credit unions from other new EU countries with a primary focus on impact of different legislative and regulatory frameworks may be undertaken. For instance, the impact of the Basel III regulatory framework on EU credit unions may be analysed as examined for the whole EU banking industry by Šútorová and Teplý (2013, 2014). Such an international 
comparison would shed more light on effects on cooperative practices advised by the WOCCU. In this case, a problem discussed earlier would be the poor data availability, however. Secondly, one may test effectiveness of new Czech credit union regulation, which came into force in 2015 and focused on promoting the cooperative spirit among members, to see whether the new legislation has changed the behaviour of Czech credit unions and their members. Thirdly, to verify the outcomes of this paper, a study using a different methodological approach or alternative proxies for financial performance measures is also more than welcome. Distinct performance measures such as economic value added, cost-to-income ratio or loan portfolio quality may be tested as dependent variables.

\section{Conclusion}

This paper empirically investigated the performance of Czech credit unions in relation with other European cooperative banks. We aimed to statistically confirm the poor stability and profitability of Czech credit unions as suggested by previous research. To do that, we created a unique dataset of 283 European cooperative banks spanning the period 2006-2013. Since numerous recent studies pointed at the persistence of profitability and stability measures, we decided to employ dynamic panel data methods (system GMM) where applicable as a main econometric tool. Profitability was measured in terms of ROAA, ROAE and NIM, while Z-Score was used as a stability measure.

Our results reveal the poor performance of Czech credit unions, which were outperformed by other European cooperative banks in ROAA and ROAE, clearly showing the lower profitability of the Czech credit union sector. We found no difference in the NIM for Czech cooperatives. Moreover, Czech credit cooperatives also suffer from lower stability. Especially striking is the adverse development in the Z-Scores of Czech credit unions, which was not observed in other countries. Signs of dependent variables used in our models are in line with findings of Hesse and Čihák (2007), whereas we find only partial consensus with other surveyed studies. This is not surprising since these studies often draw contradictory conclusions.

In conclusion, a dangerous mix of low profitability, instability and the pseudocooperative nature of Czech credit unions result in a high risk profile of these institutions. Therefore we argue that with recent capital management policies, bigger Czech credit unions will likely face serious financial problems in coming years. 


\section{Appendix}

Figure A. 1 | Z-Score Dynamics of Czech Credit Unions, 2006-2013

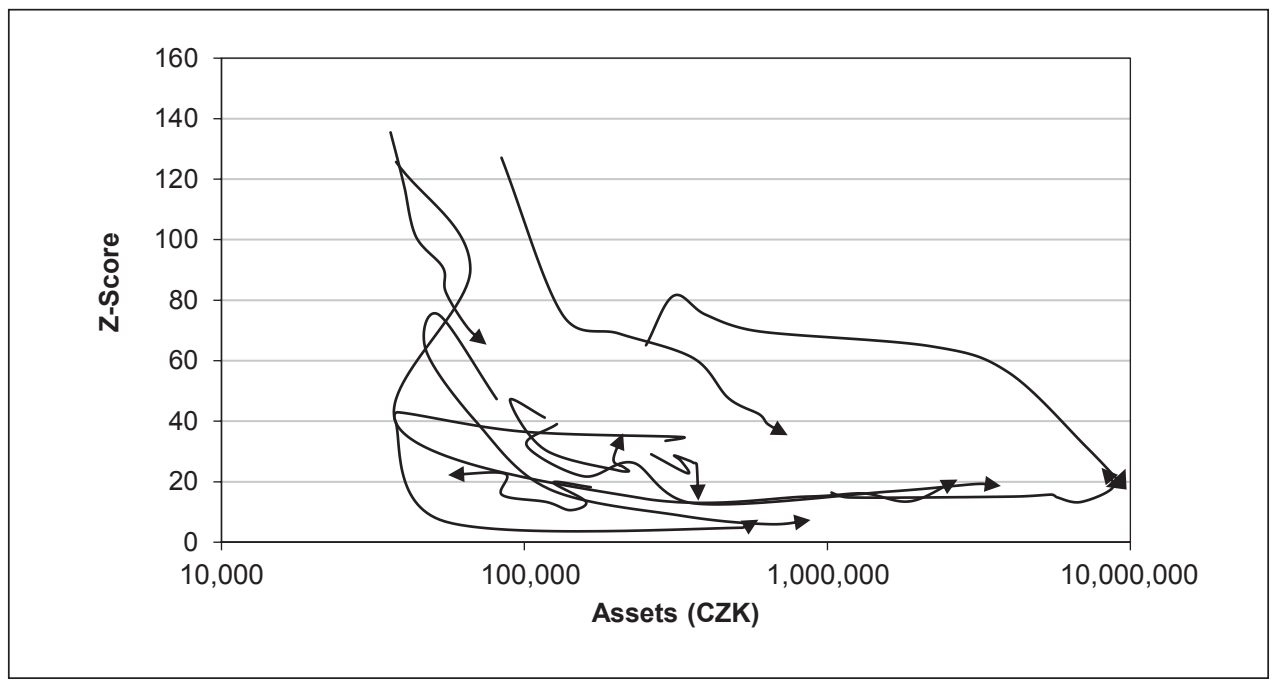

Note: Arrows show time development of individual institutions.

Source: Authors, based on BankScope and annual report data

Figure A.2 | Z-Score Dynamics of European Cooperative Banks, 2006-2013

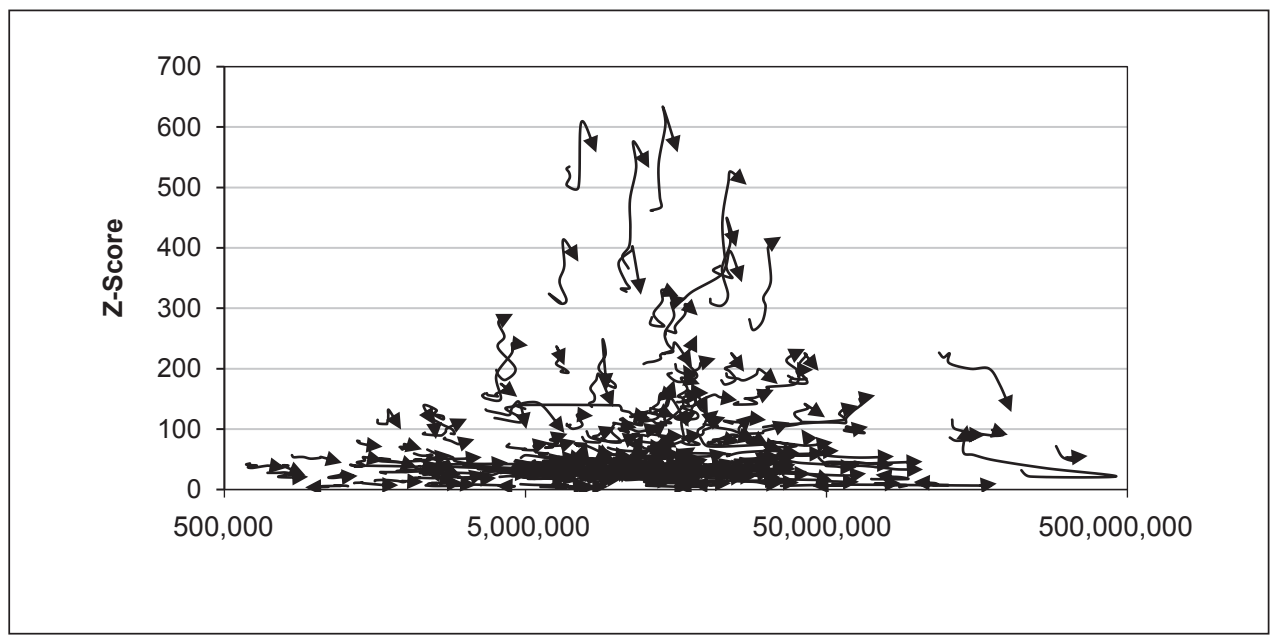

Note: Arrows show time development of individual institutions.

Source: Authors, based on BankScope and annual report data 
Table A.3 | Descriptive Statistics

\begin{tabular}{|c|c|c|c|c|c|c|}
\hline \multicolumn{2}{|c|}{ Variable } & Minimum & $1^{\text {st }}$ quartile & Median & $3^{\text {rd }}$ quartile & Maximum \\
\hline \multirow{2}{*}{ ROAA (\%) } & $C Z$ & -7.0 & 0.0 & 0.3 & 0.9 & 3.8 \\
\hline & EU & -10.2 & 0.2 & 0.3 & 0.6 & 4.3 \\
\hline \multirow{2}{*}{ ROAE (\%) } & $C Z$ & -36.9 & 0.1 & 1.6 & 5.2 & 24.0 \\
\hline & EU & -70.5 & 2.8 & 4.2 & 6.4 & 37.2 \\
\hline \multirow{2}{*}{ NIM (\%) } & $C Z$ & -0.7 & 0.9 & 1.8 & 2.8 & 7.3 \\
\hline & EU & 0.2 & 1.5 & 1.7 & 2.0 & 4.9 \\
\hline \multirow{2}{*}{ Z-SCORE } & $C Z$ & 4.7 & 16.3 & 26.9 & 51.0 & 136.5 \\
\hline & EU & 1.1 & 28.6 & 45.1 & 90.7 & 632.4 \\
\hline \multirow{2}{*}{ In_As } & $C Z$ & 10 & 12 & 13 & 14 & 16 \\
\hline & EU & 13 & 16 & 16 & 17 & 25 \\
\hline \multirow{2}{*}{$g r \_A s(\%)$} & $C Z$ & -68 & 0 & 12 & 54 & 567 \\
\hline & EU & -38 & 0 & 3 & 7 & 81 \\
\hline \multirow{2}{*}{ CAR (\%) } & $C Z$ & 3.3 & 12.8 & 18.9 & 31.8 & 100.3 \\
\hline & EU & 2.2 & 6.3 & 7.9 & 9.9 & 41.6 \\
\hline \multirow{2}{*}{ Liquidity (\%) } & $C Z$ & 0.4 & 19.4 & 37.8 & 70.0 & 100.0 \\
\hline & EU & 3.1 & 25.0 & 35.3 & 45.4 & 99.8 \\
\hline \multirow{2}{*}{ LtD (\%) } & $C Z$ & 0 & 37 & 76 & 112 & 5,838 \\
\hline & EU & 9 & 70 & 88 & 129 & 2,542 \\
\hline \multirow{2}{*}{$\begin{array}{l}\text { Loans Ratio } \\
(\%)\end{array}$} & $C Z$ & 0 & 29 & 59 & 77 & 100 \\
\hline & EU & 0 & 52 & 62 & 72 & 93 \\
\hline \multirow{2}{*}{$\begin{array}{l}\text { Cost Income } \\
(\%)\end{array}$} & $C Z$ & 0 & 73 & 83 & 95 & 431 \\
\hline & EU & 19 & 61 & 67 & 74 & 500 \\
\hline \multirow{2}{*}{ Fee Ratio (\%) } & $C Z$ & -591 & 0 & 3 & 17 & 191 \\
\hline & EU & -100 & 22 & 28 & 34 & 180 \\
\hline \multirow{2}{*}{ HHI } & $C Z$ & 0.10 & 0.10 & 0.10 & 0.11 & 0.11 \\
\hline & EU & 0.02 & 0.02 & 0.03 & 0.04 & 0.37 \\
\hline \multirow{2}{*}{ GDPgr (\%) } & $C Z$ & -4.8 & -0.7 & 2.2 & 3.4 & 6.9 \\
\hline & EU & -14.7 & 0.4 & 1.7 & 3.6 & 10.4 \\
\hline \multirow{2}{*}{$\begin{array}{l}\text { Unemploy- } \\
\text { ment (\%) }\end{array}$} & $C Z$ & 4.4 & 6.4 & 6.9 & 7.0 & 7.3 \\
\hline & EU & 3.4 & 6.1 & 7.4 & 8.4 & 24.5 \\
\hline \multirow{2}{*}{ Inflation(\%) } & $C Z$ & 0.6 & 1.4 & 2.1 & 3.1 & 6.3 \\
\hline & EU & 0.0 & 1.6 & 2.1 & 2.7 & 12.0 \\
\hline \multirow{2}{*}{$\begin{array}{l}\text { Interest Rate } \\
(\%)\end{array}$} & $C Z$ & 2.1 & 3.5 & 3.8 & 4.4 & 4.8 \\
\hline & EU & 1.4 & 3.1 & 4.0 & 4.3 & 22.5 \\
\hline
\end{tabular}

Source: Authors, based on BankScope and annual report data 
Table A.4 | Correlation Matrix

\begin{tabular}{|c|c|c|c|c|c|c|c|c|c|}
\hline Correlation & ROAA & ROAE & NIM & Z-Score & In_As & $g r \_A s$ & CAR & Liquidity & $L t D$ \\
\hline$R O A A$ & 1 & & & & & & & & \\
\hline ROAE & 0.82 & 1 & & & & & & & \\
\hline NIM & 0.28 & 0.16 & 1 & & & & & & \\
\hline Z-Score & -0.06 & -0.03 & 0.02 & 1 & & & & & \\
\hline In_As & -0.03 & 0.08 & -0.29 & 0.08 & 1 & & & & \\
\hline$g r \_A s$ & -0.02 & -0.02 & -0.08 & -0.02 & 0.11 & 1 & & & \\
\hline CAR & 0.08 & -0.05 & 0.21 & -0.07 & -0.45 & -0.01 & 1 & & \\
\hline Liquidity & -0.03 & 0.02 & -0.24 & 0.09 & -0.06 & -0.04 & -0.06 & 1 & \\
\hline LtD & -0.07 & -0.04 & 0.06 & -0.07 & -0.09 & 0.00 & 0.49 & -0.19 & 1 \\
\hline Loans Ratio & 0.05 & -0.01 & 0.23 & -0.07 & 0.04 & 0.04 & 0.07 & -0.99 & 0.20 \\
\hline Cost Income & -0.39 & -0.33 & -0.09 & -0.04 & -0.22 & 0.01 & 0.07 & -0.05 & 0.10 \\
\hline Fee Ratio & 0.05 & 0.10 & -0.16 & 0.08 & 0.24 & 0.07 & -0.17 & -0.04 & -0.02 \\
\hline HHI & -0.02 & -0.08 & -0.02 & -0.20 & -0.09 & 0.06 & 0.19 & -0.14 & 0.07 \\
\hline$G D P$ & 0.05 & 0.07 & 0.14 & 0.09 & -0.05 & 0.00 & 0.02 & 0.06 & -0.01 \\
\hline Unemployment & -0.19 & -0.22 & 0.06 & -0.13 & 0.03 & 0.02 & -0.04 & -0.14 & -0.01 \\
\hline Inflation & 0.04 & -0.02 & 0.06 & -0.13 & -0.09 & 0.01 & 0.10 & -0.12 & 0.02 \\
\hline Interest Rate & -0.06 & -0.15 & 0.10 & -0.32 & -0.06 & 0.00 & 0.12 & -0.24 & 0.12 \\
\hline$C Z$ & 0.01 & -0.07 & 0.07 & -0.08 & -0.51 & 0.00 & 0.54 & 0.12 & 0.16 \\
\hline Correlation & $\begin{array}{c}\text { Loans } \\
\text { Ratio }\end{array}$ & $\begin{array}{c}\text { Cost } \\
\text { Income }\end{array}$ & Fee Ratio & HHI & GDPgr & $\begin{array}{l}\text { Unemp- } \\
\text { loyment }\end{array}$ & Inflation & \begin{tabular}{|c|} 
Interest \\
Rate
\end{tabular} & $C Z$ \\
\hline \multicolumn{10}{|l|}{$R O A A$} \\
\hline \multicolumn{10}{|l|}{ ROAE } \\
\hline \multicolumn{10}{|l|}{ NIM } \\
\hline \multicolumn{10}{|l|}{ Z-Score } \\
\hline \multicolumn{10}{|l|}{ In_As } \\
\hline \multicolumn{10}{|l|}{$g r \_A s$} \\
\hline \multicolumn{10}{|l|}{ CAR } \\
\hline \multicolumn{10}{|l|}{ Liquidity } \\
\hline \multicolumn{10}{|l|}{ LtD } \\
\hline Loans Ratio & 1 & & & & & & & & \\
\hline Cost Income & 0.02 & 1 & & & & & & & \\
\hline Fee Ratio & 0.03 & -0.07 & 1 & & & & & & \\
\hline $\mathrm{HHI}$ & 0.11 & 0.08 & -0.13 & 1 & & & & & \\
\hline GDPgr & -0.05 & 0.03 & -0.01 & 0.07 & 1 & & & & \\
\hline Unemployment & 0.11 & 0.04 & -0.01 & 0.17 & -0.18 & 1 & & & \\
\hline Inflation & 0.11 & 0.00 & -0.10 & 0.44 & 0.34 & -0.11 & 1 & & \\
\hline Interest Rate & 0.22 & 0.05 & -0.07 & 0.20 & -0.11 & 0.55 & 0.28 & 1 & \\
\hline$C Z$ & -0.12 & 0.20 & -0.25 & 0.19 & 0.05 & -0.10 & 0.06 & 0.02 & 1 \\
\hline
\end{tabular}

Source: Authors, based on BankScope and annual report data 
Table A.5 | Profitability Regression Robustness Check

\begin{tabular}{|l|c|c|c|}
\hline $\begin{array}{l}\text { Lagged dependent } \\
\text { variable }\end{array}$ & FE & GMM & Pooled OLS \\
\hline \multirow{2}{*}{ ROAA } & -0.009 & 0.101 & $0.280^{* * *}$ \\
\hline \multirow{2}{*}{ ROAE } & $(0.027)$ & $(0.068)$ & $(0.023)$ \\
\hline \multirow{2}{*}{ NIM } & $0.053^{*}$ & $0.326^{* * *}$ & $0.364^{* * *}$ \\
\cline { 2 - 4 } & $(0.029)$ & $(0.698)$ & $(0.024)$ \\
\hline
\end{tabular}

Note: Significance codes: ${ }^{* * *}=0.01,{ }^{* *}=0.05,{ }^{*}=0.1$

Source: Authors, based on BankScope and annual report data

\section{References}

Arellano, M., Bover, O. (1995). Another Look at the Instrumental Variables Estimation of Errorcomponents model. Journal of Econometrics, 68(1), 29-51, https://doi. org/10.1016/0304-4076(94)01642-d

Athanasoglou, P. et al. (2008). Bank-specific, Industry-specific and Macroeconomic Determinants of Bank Profitability. Journal of international financial Markets, Institutions and Money, 18(2), 121-136, https://doi.org/10.1016/j.intfin.2006.07.001

Ayadi et al. (2010). Investigating Diversity in the Banking Sector in Europe - Key Developments, Performance and Role of Cooperative Banks. Brussels: CEPS.

Beck, T. et al. (2009). Bank Ownership and Stability: Evidence from Germany. WP, Deutsche Bundesbank.

Beckmann, R. (2007). Profitability of Western European Banking Systems: Panel Evidence on Structural and Cyclical Determinants. Deutsche Bundesbank. Discussion Paper No. 2007/17, https://doi.org/10.2139/ssrn.1090570

Blundell, R., Bond, S. (1998). Initial Conditions and Moment Restrictions in Dynamic Panel Data Models. Journal of Econometrics, 87(1), 115-143, https://doi.org/10.1920/wp.ifs.1995.9517

Bond, S. (2002). Dynamic Panel Models: A Guide to Micro Data Methods and Practice. Institute for Fiscal Studies. UCL, WP No. CWPO9/02, https://doi.org/10.1920/wp.cem.2002.0902

Cameron A. C., Miller, D. L. (2015). A Practitioner's Guide to Cluster Robust Inference. The Journal of Human Resources, 50(2), 317-372, https://doi.org/10.3368/jhr.50.2.317

ČNB (2014). Financial Market Supervision Report 2014. Prague: Czech National Bank.

Delis, M. D., Kouretas, G. P. (2011). Interest Rates and Bank Risk-Taking. Journal of Banking and Finance, 35(4), 840-855, https://doi.org/10.1016/j.jbankfin.2010.09.032

Dvořák, P. (2004). Analýza přičin krize českého družstevního bankovnictví. Analýza příčin a důsledků české finanční krize v 90. letech, Prague: VŠE, pp. 93-100.

García-Herrero, A. et al. (2009). What Explains the Low Profitability of Chinese Banks? Journal of Banking \& Finance, 33(11), 2080-2092, https://doi.org/10.1016/j.jbankfin.2009.05.005 
Goddard, J. et al. (2004). The Profitability of European Banks: a Cross-sectional and Dynamic Panel Data Analysis. The Manchester School, 72(3), 363-381, https://doi. org/10.1111/j.1467-9957.2004.00397.x

Goddard, J. et al. (2010). Do Bank Profits Converge? European Financial Management, 19(2), 345-365, https://doi.org/10.1111/j.1468-036x.2010.00578.x

Hesse, H., Čihák, M. (2007). Cooperative Banks and Financial Stability. International Monetary Fund. Washington D. C. WP, No. 07/02, https://doi.org/10.5089/9781451865660.001

Iannotta, G. et al. (2006). Ownership Structure, Risk and Performance in the European Banking Industry. Journal of Banking and Finance, 31(7), 2127-2149, https://doi.org/10.1016/j. jbankfin.2006.07.013

IMF (2012). Selected Issues on the Credit Union Sector - Technical Note. Washington D.C.: IMF.

Köhler, M. (2012). Which Banks Are More Risky? The Impact of Loan Growth and Business Model on Bank Risk-taking. No. 33/2012, Deutsche Bundesbank.

Lepetit, L., Strobel, F. (2013). Bank Insolvency Risk and Time-varying Z-score Measures. Journal of International Financial Markets Institutions and Money, 25, 73-87, https://doi.org/10.1016/j.intfin.2013.01.004

Liikanen, E. et al. (2012). High-level Expert Group on Reforming the Structure of the EU Banking Sector. Brussels: European Commission.

Liu, H. et al. (2013). Competition and Stability in European Banking:

a Regional Analysis. The Manchester School, 81(2), 176-201, https://doi. org/10.1111/j.1467-9957.2011.02285.x

Matejašák, M., Teplý, P. (2013). Kampeličky jako dynamit na českém trhu? Český finanční a účetní časopis, 8(1), 33-47, https://doi.org/10.18267/j.cfuc.331

MFČR (2014). Závěrečná zpráva o hodnocení dopadů zákona, kterým se mění zákon č. 87/1995 Sb. Prague: MFČR.

Moulton, B. R. (1986). Random Group Effects and the Precision of Regression Estimates. Journal of Econometrics, 32(3), 385-397, https://doi.org/10.1016/0304-4076(86)90021-7

Nickell, S. (1981). Biases in Dynamic Models with Fixed Effects. Econometrica, 49(6), 1417-1426, https://doi.org/10.2307/1911408

Shehzad, Ch. T. et al. (2009). Growth and Earnings Persistence in Banking Firms: A Dynamic Panel Investigation. CESifo Group Munich. WP No. 2772.

Sútorová, B., Teplý, P. (2013). The Impact of Basel III on Lending Rates of EU Banks. Czech Journal of Finance, 63(3), 226-243.

Šútorová, B., Teplý, P. (2014). The Level of Capital and the Value of EU Banks under Basel III. Prague Economic Papers, 23(2), 143-161, https://doi.org/10.18267/j.pep.477

Tomšík, V. (2015). Rozlišujeme meze družstevnictvím a bankovnictvím. Bankovnictví, 1. Prague.

Windmeijer, F. (2005). A Finite Sample Correction for the Variance of Linear Efficient Two-step GMM Estimators. Journal of Econometrics, 126(1), 25-51, https://doi.org/10.1016/j. jeconom.2004.02.005

WOCCU (2011). Model Law for Credit Unions. World Council of Credit Unions. 